\title{
The main currents (schools) of thought about the informal economy
}

\author{
Cristian MARINESCU ${ }^{1}$ \\ Ileana VALIMĂREANU (MIRCIOI) ${ }^{2}$
}

\begin{abstract}
Starting from the various interpretations of the concept of "informality", which can be associated with both negative aspects (underground economy, tax evasion, undeclared work, lack of productivity, lack of social protection, unfair competition) and positive aspects (a source for the poor, who have no alternative), this paper aims to review the main conceptual debates over the term "informality", opinions that can be synthesized in four currents or schools of thought, respectively: The dualist school, Structuralist School, Legalistic School and Voluntaristic School
\end{abstract}

Keywords: the informal economy, fiscal system

JEL classification: E26, O17

DOI: $10.24818 /$ RMCI.2019.3.312

\section{Introduction}

Since its emergence in the early 1970s, the concept of "informal economy" has been the subject of wide debates amongst both economists (Hart, Maloney, Fields, Haris, Todaro, etc.) and institutions, that have been preoccupied with labor market study (International Labor Office, World Bank, etc.).

"Informaityl" is encountered in economic theory under a type of names, so if we refer to the labor informality we come across names like: informal sector (Hart Keith, 1973), undeclared work (European Commission, 1998), informal economy, occupation in the informal sector and informal employment (ILO, 1993/2003), invisible or hidden occupation (OECD, 2004), and if we refer to "informality" in a general sense, the literature uses concepts such as dual economy, tax evasion (as a practice of informality), underground economy, shadow economy.

Generally, most specialists associate the term "informality" with something negative (unprotected workers who do not benefit from social security, poor productivity, unfair competition, excessive legislative regulations, non-payment of taxes to the state budget, "black work"), but there are authors who consider the

${ }^{1}$ Cristian Marinescu, Romanian Court of Accounts,

E-mail: cristian.marinescu@macroeconomie.ro;

${ }^{2}$ Ileana Valimăreanu, Bucharest University of Economic Studies,

E-mail: ileanamircioi@gmail.com; 
informal economy to be something positive, which is a source of income for the poor, who opt for the informal economy because it is the only sector that ensures their subsistence.

Another point of view of informality is that, empirically, informality does not exist as such, being merely a way of expressing the lack of formality, being the contrast of those economic principles considered as part of the Orthodox nucleus of economic science (Marinescu, Valimareanu, 2018).

These debates on informality are concluded in several opinions that can be synthesized in four schools of thought, namely dualist school, structuralist school, legalistic school, voluntaristic school, wich add the holistic approach of the informal sector.

\section{The Dualist School}

According to this trend of thinking, the informal sector of the economy is made up of small-scale activities that are different and not related to those in the formal sector of the economy and that provide the income of the poor, as well as a safety net in the crisis of those who can not work in the formal sector of the economy. The representative work that promotes this stream of thought belongs to Hart (1973), the International Labor Office (1972), Sethuraman (1976), Tokman (1978).

The partisans of this stream of thought are of the opinion that people working in the informal sector of the economy are excluded from the formal economic sector from two causes, namely: on the one hand, due to an imbalance between population growth rates and employment rates (population is growing faster than the formal economy is capable of generating new jobs) and on the other hand because of the low flexibility of workers that make a difference between the professional training and the skills of the workers and the employers' requirements in the formal area of the economy.

As a solution to diminishing the informal sector of the economy, dualists argue that governments should create more jobs and give informal economic agents access to credit and business development programs as well as social protection services for their families.

\section{The Structuralist School}

According to the stream of structuralist thought, informality is due to capitalism and capitalist growth. In contrast to the dualists, structuralists believe that formal and informal forms of production are interdependent, and the growth of the informal economy is due to the nature of capitalist development rather than the lack of economic growth, as the dualists claim.

Increased competition and the market competitiveness, the reaction of formal firms to the increased bargaining power of employees, due to the strong unionisation of formal employees, excessive state regulations (especially the tax system and social legislation), global competition, new methods of competition of the postmodern world 
(offshore industry, subcontracting chains, multinational companies etc.) causes formal firms to reduce their production costs and especially labor costs.

In this process step in the small and informal firms or informal employers that employ informal workforce and offer low-priced services to formal societies in a relationship of subordination to them.

As solutions to diminishing informality, structuralists propose public policies to address the unequal relationship between large, formal firms and informal, subordinate firms that offer cheap labor.

Practically, cross-sectoral relationships arise due to the large inequalities between formal businesses and those developed by informal firms. This is particularly the case of developing or transition economies where multinational companies, when they enter a market in an emerging economy with their financial strength, allow themselves to practice for a while at times even below the cost of production, until they finally eliminate their competition, respectively the small domestic firms that will no longer be competitive to stay in the formal sector of the economy and for this reason they will enter in the informal economy. Here, they will shortly be subordinated to a large company, and will survive, especially through fiscal noncompliance.

\section{The Legalistic School}

Legalist current sees the informal sector of the economy as consisting of informal entrepreneurs choosing to operate informally in order to avoid costs, time and effort for formal registration. Legalists believe that cumbersome bureaucracy creates barriers to formalization and thus inhibits the productive potential of informal entrepreneurs. Among the prominent representatives of the law school are Soto $(1989,2000)$.

As a solution to diminishing informality, legalists believe that the state should simplify bureaucratic procedures to encourage informal entrepreneurs to register and extend the legal rights to property for assets held by informal businesses so that they can capitalize on their productive potential by converting the assets they own in addition value.

\section{The Voluntaristic School}

The voluntaristic school considers the informal sector of the economy as consisting of economic agents who choose to operate informally in order to avoid fiscal, financial and commercial regulations of the state. Unlike legalists, the voluntaristic school does not invoke the complicated bureaucracy of formality, but only the financial benefits of informality by tax payments elusion, this option being the result of a cost-benefit analysis of the two sectors of the economy. The principal representative of the volunteer school is William Maloney.

In assessing the opportunity cost of choosing the informal sector of the economy, economic agents also take into account contraventional or penal sanctions the informality. 
In order to reduce informality, voluntarists propose public measures that usually aim at relocation of the fiscal system by reducing fiscal pressure, widening the tax base, more drastic measures to sanction informal operators, and better regulation of the tax framework, knowing that the tax evasion practiced by economic agents encompasses both the "illicit" (tax fraud) and the "licit" form (at the limit of the law), the latter speculating on the existing "legislative vacuum" in a state (Maloney, 2004).

\section{The holistic approach of the informal sector}

The informality debates between the four dominant schools of thought have brought more light to this concept, even though each of these schools has focused on one or the other of the causes and motivations of the informal sector of the economy. None of the above-mentioned schools of thought have dealt with informality as a whole: the dualists have focused on small-scale activities that prefer informality in tradition or for survival; structuralists consider informality as a factor in the development of capitalism, and legalists and voluntarists have emphasized bureaucracy and high fiscal pressure as the causes of informality, so the voluntary option to informality.

The informal economy is, as a whole, more heterogeneous and complex than the sum of these perspectives brought into question by the four currents of thought. For this reason, holistic approaches to the informal economy have emerged that take into account all aspects of informality and all categories of informal workers.

Such an approach is developed in the paper published in 2007 entitled "Informality: exit and exclusion" by a team of scientists from the World Bank (Latin America Division) headed by Guilermo Perry and William Maloney who, that have developed a holistic model explaining the informality.

Another holistic approach to informality belongs to Ravi Kanbur (2009). In 2009 , it set out a conceptual framework to distinguish between four types of economic responses to legal regulations, namely:

- Those who are within the scope of, and comply with, legal regulations;

- Those who remain in the legal regulations but do not comply;

- Those who adjust their work to circumvent legal regulations;

- Those who are outside the scope of the law and do not need to adjust their work to circumvent legal rules.

\section{Conclusion}

From our point of view, the differences in the approach of the concept of "informality" between the four schools of thought are due both to the different interpretation of the informal sector of the economy but, in particular, to the different legislative framework under which the research was carried out due to the differences existing legislation in countries where researchers have conducted their studies. Here are the different conclusions, which is why we consider it important

Review of International Comparative Management $\quad$ Volume 17, Issue 5, December $2016 \quad 315$ 
that informality needs to be approached holistically, taking into account all aspects of informality and all categories of informal workers.

\section{Bibliography}

1. Fields Gary S., 1975, "Rural-Urban Migration, Urban Unemployment and Underemployment, and Job Search Activity in LDC's," Journal of Development Economics 2: 165-188.

2. Fields Gary S, 2008, "Segmented Labour Market models in developing countries", Cornell University ILR School, paper 162.

3. Hart Keith, 1973, "Informal income opportunities and urban employment in Ghana", Journal of Modern African Studies 11, 61-89.

4. Hart Keith, 2011, "Informal economy", The Memory Bank.

5. ILO, 1972, "Employment, Incomes and Equality. A strategy for increasing productive employment in Kenya", International Labour Office (ILO), Geneva.

6. ILO, 2002, "Decent Work and the informal economy", Report of the DirectorGeneral presented to the 90th International Labour Conference, International Labour Office, Geneva.

7. Kanbur Ravi, 2009, "Conceptualizing Informality: Regulation and Enforcement", Indian Journal of Labour Economics, February.

8. Maloney William F., 2004, "Informality Revisited", World Development no. 32 (7): pg: 1159-78.

9. Marinescu C., Valimăreanu I, 2018, "Methodological and Theoretical Considerations regarding Informality on the Labor Market", Revista de Management Comparat International, vol. 19, nr. 1, pg. 54-64.

10. OECD, 1994, "The Jobs Study. Facts, analysis, strategies", p. 1-55.

11. Perry Guilermo, Maloney William and col., 2007, „Informality: Exit and Exclusion", The World Bank, Washington DC.

12. Schneider Friedrich, Enste Dominik, 2000, „Shadow Economies: Size, Causes and Consequences", Journal of Economic Literature, 38 (1), 77-114.

13. Sethuraman S.V., 1976, "The Urban Informal Sector: Concept, Measurement and Policy", International Labor Review, 114, 1, pg 69-81.

14. de Soto H., 1989, "The Other Path. The Invisibles Revolution in the Third, World", New York: Basic Books.

15. Tokman, V., 1978, "An exploration into the nature of informal-formal sector relationships", World Development 6, pg: 1065-1075.

16. Tokman, V., 1992, "The Informal Sector in Latin America: From Underground to Legality", In Beyond Regulation: The Informal Economy in Latin America, ed. V. Tokman. Boulder, CO: Lynne Rienner. 